\title{
Corrigendum: The Stand-Alone PilZ-Domain Protein MotL Specifically Regulates the Activity of the Secondary Lateral Flagellar System in Shewanella putrefaciens
}

\author{
Anna Pecina ${ }^{1}$, Meike Schwan ${ }^{1}$, Vitan Blagotinsek ${ }^{2}$, Tim Rick ${ }^{1}$, Patrick Klüber $^{1}$, \\ Tabea Leonhard ${ }^{1}$, Gert Bange ${ }^{2}$ and Kai M. Thormann ${ }^{1 *}$ \\ ${ }^{1}$ Department of Microbiology and Molecular Biology, Justus-Liebig-Universität Gießen, Giessen, Germany, ${ }^{2}$ Department of \\ Chemistry, SYNMIKRO Research Center, Philipps-University Marburg, Marburg, Germany
}

Keywords: flagella, c-di-GMP, flagellar motor, YcgR, Shewanella, PilZ domain, lateral flagella

\section{OPEN ACCESS}

Edited and reviewed by: Seiji Kojima,

Nagoya University, Japan

${ }^{*}$ Correspondence: Kai M. Thormann kai.thormann@mikro.bio.uni-giessen.de

Specialty section: This article was submitted to Microbial Physiology and Metabolism, a section of the journa Frontiers in Microbiology

Received: 16 June 2021 Accepted: 28 June 2021 Published: 16 July 2021

Citation:

Pecina A, Schwan M, Blagotinsek V, Rick T, Klüber P, Leonhard T, Bange $G$ and Thormann KM (2021)

Corrigendum: The Stand-Alone PilZ-Domain Protein MotL Specifically

Regulates the Activity of the Secondary Lateral Flagellar System in Shewanella putrefaciens. Front. Microbiol. 12:726192. doi: 10.3389/fmicb.2021.726192

\section{A Corrigendum on}

The Stand-Alone PilZ-Domain Protein MotL Specifically Regulates the Activity of the Secondary Lateral Flagellar System in Shewanella putrefaciens

by Pecina, A., Schwan, M., Blagotinsek, V., Rick, T., Klüber, P., Leonhard, T., et al. (2021). Front. Microbiol. 12:668892. doi: 10.3389/fmicb.2021.668892

In the original article, there was a mistake in Figure $\mathbf{1}$ as published. The alignment shown in 1D for DgrA was not correct. We also updated the signature motif for the c-di-GMP-bindig motif of PilZ domains with a more recent one. The corrected Figure 1 appears below.

In the original article, there was an error. In the text appeared an older version of the c-di-GMP-binding motif within PilZ domains. We have updated the information along with the corresponding reference.

A correction has been made to Results, Identification of a flagellar motor effector protein in Shewanella putrefaceins, 2nd paragraph:

Sputcn32_3446, annotated as a PilZ domain, is located 34 bp downstream of motB and transcribed in the same direction (Figure 1B). The gene is $435 \mathrm{bp}$ in length and encodes a protein of 144 aa with an estimated molecular mass of $16.6 \mathrm{kDa}$ and a theoretical $\mathrm{pI}$ of 5.94. The protein is thus much smaller than YcgR (244 aa), FlgZ (263), and MotI (217aa) as an N-terminal YcgR domain is not present (Figure 1C). The predicted c-di-GMP-binding motifs (RxxxRhxh, DhSxxG; Galperin and Chou, 2020) are fully conserved (Figure 1D). The protein is conserved in a number Shewanella species that possess dual flagellar systems, and the gene it is always located downstream of motB. Potential homologs of Sputcn32_3446 are also present in some species of Aeromonas and Vibrio, but absent from the well-characterized $V$. parahaemolyticus and $V$. alginolyticus, which also possess two distinct flagellar systems. We henceforth referred to the protein as MotL, relating to its location within the lateral flagellar gene operon and its differences to YcgR, FlgZ, and MotI with respect to the protein sequence and absence of further domains.

The authors apologize for this error and state that this does not change the scientific conclusions of the article in any way. The original article has been updated. 
A

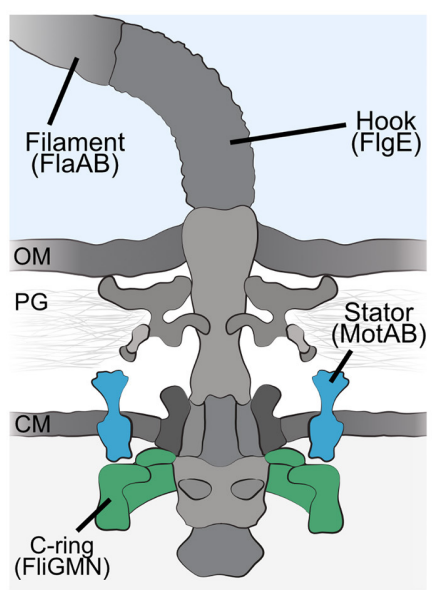

B

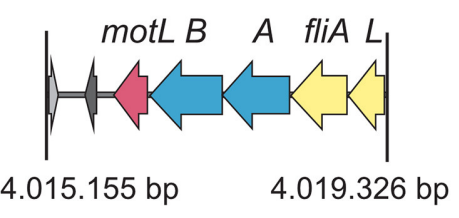

C

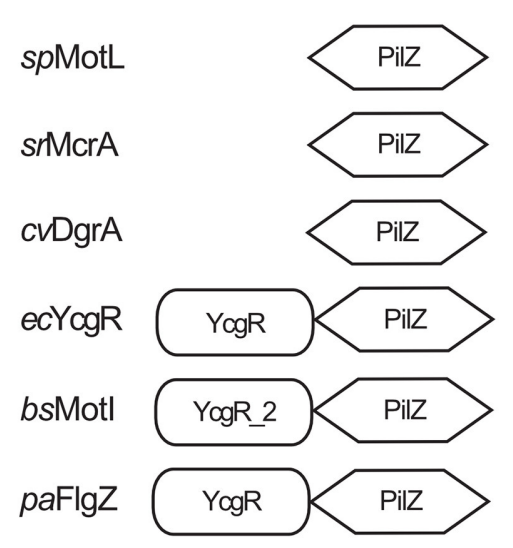

\section{RxxxRhxh DhSxxG}

spMotL RTHQRLSL AN IKDISIGGV

SrMCrA RASSREET : GIVVDLSDEG I

cVDgrA RAHPRMPA ASLLDVAEKGG

ecYcgR RRYFRISA I FRL YDLSLGGM

bsMotl RQYVRTDA TLSYN I SAGG I

paFIgZ RNAYRASI: GQLLDISATGA

\section{REFERENCES}

Galperin, M. Y., and Chou, S. H. (2020). Structural conservation and diversity of PilZ-related domains. J. Bacteriol. 202:e00664-19. doi: 10.1128/JB. 00664-19
Copyright (c) 2021 Pecina, Schwan, Blagotinsek, Rick, Klüber, Leonhard, Bange and Thormann. This is an open-access article distributed under the terms of the Creative Commons Attribution License (CC BY). The use, distribution or reproduction in other forums is permitted, provided the original author(s) and the copyright owner(s) are credited and that the original publication in this journal is cited, in accordance with accepted academic practice. No use, distribution or reproduction is permitted which does not comply with these terms. 